\title{
The Role of "eTrash2Cash" in Curtailing "Almajiri" Vulnerability in Nigeria Through Waste Management Social Micro-entrepreneurship
}

\author{
Alh. Muhammad Salisu Abdullabi
}

\section{INTRODUCTION}

The northern region of Nigeria is commonly associated with the term Almajiri, ${ }^{1}$ a system of religious education. In Almajiranci, ${ }^{2}$ poorer families send their children away from home to seek knowledge through an Islamic education based on the Holy Qur'an, with traditional teachers known as Mallams serving as the children's guardians. These children, who are mainly between the ages of 5 and 19, are sent over long distances across the northern states, usually to specified destinations. But their Mallam guardians are proscribed by tradition from providing anything to

${ }^{1}$ The term originated from the Arabic word Almubajir, which means a migrant. It was used in history to describe patriots of the holy Prophet Muhammad who migrated from Mecca to Medina during the early days of the Islamic religion.

${ }^{2}$ Almajiranci is the term being used to describe the system of Almajiri education.

A. M. S. Abdullahi $(\bowtie)$

eTrash2Cash, eT2C Company Nigeria, Azare, Nigeria

(C) The Author(s) 2020

M. L. McLean (ed.), West African Youth Challenges and

Opportunity Pathways, Gender and Cultural Studies in Africa and the Diaspora, https://doi.org/10.1007/978-3-030-21092-2_10 
support their living. In the rare instances in which children are taken to unspecified destinations where they know no one, the children's parents or their guardians look for the established traditional schools in their final destination and settle there. Whatever the children's final destination, the expectation is that they undertake small jobs and fend for themselves by begging. In the rainy season, they are expected to help their designated Mallam with his own family's needs by doing farm work.

The National Council for the Welfare of the Destitute (NCWD) (2001) puts the current population of the Almajiri in Nigeria at about seven million. According to Abdulkadir (2010), children who comprise this population fall into two broad categories: the most vulnerable are children aged 5 to 11 and vulnerable youth are those aged 12 to 26 . Most of them are from the Hausa-/Fulani-speaking ethnic groups and have little or no formal education (Abdulkadir, 2010).

Historically, between the eighteenth and nineteenth century when great centers of Islamic learning were established and flourishing, the phenomenon was a recognized and acceptable socioreligious practice. However, with a challenging economic situation in the country, many in the rural areas in Hausaland are pressured to move to the urban communities to better their livelihoods. This makes the practice of Almajiranci widespread amongst low-income rural parents, bearing further negative consequences on the welfare of innocent children entrusted to a Mallam who would take them elsewhere to impart a proper Islamic education.

The issue of Almajiranci in Nigeria as a whole, and particularly in northern Nigeria, has been an integral part of the country's social challenges for decades. Multiple attempts have been made by scholars and researchers, political leaders and other well-meaning Nigerians to conceive of and implement a lasting solution to curb the rampant increase of Almajiranci. Some have alleged that the practice is a cheap avenue for recruiting agents for violence and terrorism, but these allegations have not been supported by sound research (Ogunmade, 2013). However, the increasing prevalence of Almajiranci has been documented by researchers, who attribute the trend to parents who see it as the most expeditious avenue of enrolling their children in the informal Qur'anic schools which they find culturally acceptable and can afford (Hoechner, 2011).

The eTrash2Cash project was conceived and launched as a social enterprise to bring an immediate solution to the Almajiri social issue in Nigeria. The project provides the victims with professional training that enables them to earn money from resource recovery, waste collecting activities 
that simultaneously clean the local environment and boost economic growth.

This chapter is divided broadly into two parts: the first section provides a more detailed description of the current practice of Almajiranci in northern Nigeria, by exploring the author's personal experience; the perceived viability, attractiveness, challenges, and impact on child discipline; and the documented economic and social effects. The second section discusses the sustainable eTrash2Cash solution, the history of the enterprise, its youth employment and entrepreneurship program, and how the victims benefit from it and other similar programs.

\section{Description of Almajiranci in Northern Nigeria TODAY}

Critics of the current practice of Almajiri in northern Nigeria point to evidence that it has a completely different meaning than it did traditionally. Today, the term Almajirai (the plural form of Almajiri) is conventionally used to refer to beggars, or people who cannot provide for themselves and thus roam the streets in Nigeria's towns and cities. These critics, including the reformist Islamic scholars in Nigeria, bemoan the farreaching negative impact on the children and youth deprived of the comfort and protection of their own homes and parents at a very tender age and also on the nation, which is deprived of the contributions of future leaders, young people who might otherwise have grown up to enter respectable vocations as judges, accountants, and engineers (Sa'id, 1992).

Because, according to the practice, the Mallam guardian is not responsible for feeding the Almajiris, the children are forced to beg for food and other basic necessities of life (Garba, 1996), roaming the hot streets, approaching passengers in cars and pedestrians for money or alms. The children are completely dependent upon strangers - and each other-for their food, shelter, and other basic needs, which often go unmet (Ibrahim, 2008). In this process, they become victims of economic hardship, child neglect, and abuse, all in the name of Qur'anic education (Salis, 1995).

As Almajiris roam the streets, motor parks, and marketplaces and go from door to door begging for food and other necessities of life, some attach themselves to sellers of Hausa daily food items such as beans cake, breads, and groundnut cakes, in hopes of attracting sympathy from customers inclined to share some portion of their food purchases (Babangida, 
1993). Most Almajiris temporarily migrate to the city from rural areas to look for greener pastures (Ibrahim, 2008). Most of them travel to nearby cities, with a few of them traveling as far as Lagos or even neighboring African countries like Benin, Senegal, and Chad. The availability of Almajiris as a source of cheap labor is believed to contribute to adult unemployment in northern Nigeria's poorest communities. At a number of public places such as markets and cinema houses, disputes arise between Almajirai and non-Almajirai adults over who should be paid for looking after parked vehicles. The unprecedented influx of migrants from the neighboring African nations, such as Ghana, Mali, and Niger among others, is a compounding factor.

The children and youth receive Qur'anic religious instruction inside Almajiri schools, which are usually situated on the premises of the local mosque or tsangaya, an informal building meant for the Qur'anic school. Religious instruction can also take place outside of formal classroom settings, in the vicinity of the Mallam's house, under the shade of a tree, and with slates as reading materials (Ya'u, 2001). Rather than follow a standard curriculum, most of the Qur'anic schools have developed their own syllabi, methodology, school calendar, and curriculum.

The conditions under which the Almajiris are expected to learn can be challenging to their physical as well as mental health. They usually receive instruction while sitting on the bare floor, as most of the schools cannot even afford mats, and live in congested tiny classrooms, which mostly serve as both their schooling and sleeping places. The Almajiri schools are normally not coeducational; it is a very rare instance for a girl to be sent for Almajiri education away from her place of birth. Even in Almajiri schools where girls participate as day students (who study during the day and return home to sleep in their parents' houses), they are clearly separated from the boys. These informal Almajiri schools have an average population of 180 pupils, the majority or all being boys, under the control of one Mallam. Without a formal register for the students, it is very difficult for the Mallam to determine daily attendance and absenteeism of his students.

It is not uncommon for all instruction to take place in one small classroom which has a normal capacity of 50 pupils or so, certainly far less than 180 (Sule, 1994). Toilet facilities, where available, are limited and in the most unhygienic conditions. Because of the large number of these children under the care of one Mallam, himself being a low-income earner, it is not uncommon to find an Almajiri school without any toilet facility. In 
these situations, the Almajiri resort to the use of bushes, city outskirts, or other uncompleted buildings, if available, for any toilet needs.

Amidst the health hazards, the Almajiris of today cannot even afford the most basic health services; therefore, they receive no treatment for common ailments or injuries they may face like diarrheas, wounds, and malaria fever, which can be directly traced to their unhygienic vulnerable conditions and exposure. Some do buy medicine to treat themselves, prescribed by medical personnel such as nurses that support the system and purchased from drug stores. Even where there should be free hospitals and health services, because of their socially marginalized positions they cannot be treated (Perverz, 2005).

To supplement begging, some Almajirai take up menial job services as plate washers in restaurants and even prohibited places, such as commercial sex workers' houses, hotels that serve alcohol, and bars and clubs, which may lead to some intermingling with adults engaged in undesirable behaviors.

Almajiris are also vulnerable to exploitation by the Mallams to whom their parents entrusted them. They become part of an informal child labor system in which they are forced to earn a living by begging not only to feed themselves but also to contribute to the welfare of the Mallam's household by working on the Mallam's farm, fetching water for his domestic use, collecting fire wood, and sometimes even contributing part of what they get from begging (Sulaiman, 1996). Also, the Almajiris are prone to hearing all kinds of embarrassing words, such as curses on them and their parents who sent them on the mission, insults on their faces, verbal expressions to humiliate them, and so on, which are potentially damaging to both the psychological and physical development of a child or young person (Kabir, 2002). It has never been easy for the Almajiri child, whose life experience is influenced by growing up in an environment of disapproval and often various forms of maltreatment, open assault, and contempt for only being Almajirai (Hoechner, 2011). There is a perceived emotional instability associated with distress which results from the accumulated psychological effects of exposure to rejection; this would probably explain reported cases of suicide committed by Almajiri children for undocumented reasons.

Traditionally, and now, mostly amongst the rural populace, the system of Almajiranci is valued and regarded highly for its Qur'anic education, which implies religious devotion and is considered to be an avenue to building moral character. Because of the strict hardships associated with 
the Almajiranci journey, the children are forced to train themselves in virtuous characteristics like being extremely patient and humble, which are highly regarded as very valuable life skills in rural settings, as well as the core elements of the Islamic faith the Almajiri children believe in (Ware, 2014).

Recent research illustrates how deep-rooted extreme poverty and a lack of access to better alternatives fuels the Almajiri practice (Hoechner, 2015), which has gradually transcended to something that looks like major forms of child abuse. The practice is common among polygamous, poor, and uneducated families (Perverz, 2005). Hoechner (2015) has shown that the Almajiri phenomenon persists even though it no longer promises access to political power or increased social status-that is, in spite of the fact that its economic viability has been undermined and its religious merit has come under attack. Structural factors constraining the opportunities available to poor peasant households play an important role in fueling its demand. The decline of Nigeria's rural economy in response to the oil boom beginning in the mid-twentieth century, the structural adjustment program imposed by the World Bank and International Monetary Fund in the mid-1980s, along with the country's massive demographic growth-its population has more than quadrupled since 1950 (United Nations, 2008)-all combined to create distortions in what was formally viewed as a normal rite of passage for Muslim youth. The result is the perpetuation of both poverty and educational disadvantage. The poor quality of Nigeria's modern education system, particularly in rural areas, its costs (students are routinely expected to obtain their own books and other school supplies), its association in the public's memory with the Christian missionaries that first offered it during the colonial era, and its low returns in terms of employment account for low enrollment rates. The erosion of the rural economy simultaneously leads many to migrate seasonally, or permanently, to the cities. Faced with such constraints, families make sense of their decisions to send their children to live as Almajirai in the urban centers not only with reference to their high regard for Qur'anic learning, but also mindful of the educational value of a certain degree of hardship for the social and moral training of their children (Hoechner, 2015). 


\section{Personal Experience on Almajiranci}

I was born and bred in Azare (Bauchi State) of middle-class religiously observant parents. My primary and secondary school education took place in day schools, while I received religious instruction through the reformist modern Islamic education classes in the evenings. Through my teenage years I saw firsthand how the typical Almajiri child was viewed negatively in the society and suffered from gross neglect from his parents. I befriended many Almajiri children and their Mallam guardians within my neighborhood, as my parents would often provide housing for the Almajiri and their Mallams. This made it possible for me to gain the young people's trust and to witness both their vulnerability and resilience in the situations they were trapped in.

Several Almajiri friends I made in this way confided life secrets that helped me to understand how a major change in circumstance-for instance, the death of a parent-compelled their family caregivers to send them on the "sacred" mission. My Almajiri friends would openly express how they wished they were in my situation, with parents who lived and worked in the city and could afford to send me to school and otherwise provide for me. I gained their trust to the extent that they entrusted me to help them set aside portions of their personal earnings to be used for special circumstances, like emergencies and to buy new clothing on festive occasions. The majority of them earned a living from pushing carts to sell water during lesson-free days.

For several years I observed how hard-working and full of hope and vision most of the Almajiri I encountered were, but I also saw how the hardship and vulnerability they faced made some of them easy recruits for unleashing violence and thuggery.

However, overall, in my own personal conviction and from experience, I believe that the majority of Almajirai, if given the chance and resources, would be better citizens and follow every norm that deviates from any ugly path of violence or civil unrest.

I recall my childhood Almajiri friend, Sallau, ${ }^{3}$ who lived with his Mallam next door and was orphaned at the age of one. He memorized the Holy Qur'an at the age of 13, and went on to start secular education from scratch, toiling with his own hands to pay every cost of his education without the support of anyone. Today, he is a proud Almajiri who works as a

\footnotetext{
${ }^{3}$ Pseudonym used; real name withheld for privacy.
} 
banker with a first class degree in Accounting from Bayero University, Nigeria. Another instance is Adamu Garba II, who rose from being an Almajiri to become a founder of one of the biggest software and technology companies in the country and who is making plans to run for political office. Many similar instances of individuals who grew up Almajiri, and who either persevered and overcame their circumstances or, as was more commonplace, could not overcome the odds stacked against them and remained trapped in poverty and handicapped by the physical and emotional injuries inflicted on them from a young age, inspired me into critical thinking for a sustainable solution to support Almajiri youth.

Notwithstanding the few Almajiri people who overcame poverty and are doing well to some extent, as Hoechner (2015) has opined, due to the obvious lack of political will and poor economy in northern Nigeria, the likelihood for the Almajiri people to escape poverty and have a successful and bright future is very limited. Inusa ${ }^{4}$ and Sirajo ${ }^{5}$ are also my Almajiri friends from childhood; neither of them have memorized all parts of the Qur'an for more than two decades now, and they have not made significant progress in studying Western knowledge. The former, a bit responsible, works as a bus conductor earning less than $\$ 25$ monthly to support his one wife and six children. The latter has the worst case scenario; he is a drug addict with very little likelihood to make any meaning of his life, whose own relatives have abandoned him for years without wanting to even hear how his life goes.

From the outset I knew that a feasible solution would have to come to terms with the fact that the present-day practice of Almajiri is perceived as a viable and attractive form of education by the people who both believe in and are victimized by it.

\section{Perceived Advantages and Impact of Almajiranci}

While critics regard Almajiranci as a throwback to "backward" tradition to the poor families in northern Nigeria who practice it, it is an alternative to the so-called modern education system in which they have lost all confidence. Khalid (2013) made known during a presentation delivered at the Nigerian National Symposium on Almajiri Education that the traditional and religious Almajiri schools are the preferable choice for many traditional

\footnotetext{
${ }^{4}$ Real name withheld for privacy.

${ }^{5}$ Real name withheld for privacy.
} 
Muslim Hausa/Fulani societies for several reasons. First, the flexibility in their timetable makes it suitable for rural communities that rely solely on agriculture as occupation and also allows every student to progress at his own pace. Further, the multiple entry points of the traditional Almajiri schools allow parents to enroll their children anytime they wish, scheduling their children's enrollment around seasonal agricultural activities, unlike the formal schools that have single entry points at the beginning of the academic year. Dr. Khalid also noted that the schools' egalitarian outlook and affordability (incurring zero or very few costs for school fees, uniforms, texts and notebooks, feeding and transport money, etc.) are also extremely attractive to parents, since they can barely afford such expenses. Above all, these schools do not prevent children from partaking in their traditional occupations as the formal schools would.

Apart from education, Almajiranci is also viewed as a place for instilling discipline in children and youth. It is believed that Almajiranci teaches young people to be dutiful to their parents, teachers, and the larger society. The system is also regarded as a last resort for rehabilitating the youth who are labeled as undisciplined and stubborn, or kangararrun yara. Some parents are of the belief that the modern "reformist" Islamic schools, Makarantar Islamiyya, are not of the same disciplinary level as the Almajiri school, hence a perceived advantage of the Almajiranci. Most Almajiri schools have strict disciplinary codes, and will, for instance, expel a student for stealing or fighting, and inflict heavy punishment for lying. Some schools go to the extent of using chains for beating the legs of "the stubborn ones" (M. Ibrahim, personal communication, December 16, 2017; Anas, 2017).

The preceding section of this chapter described how Almajirai functions as a source of cheap labor. In cities like Kano, youth perform menial jobs for their subsistence. The youngest children are especially inclined to accept whatever compensation they are given in return for their services rendered. The fact that so many children are floating laborers, especially in Hausaland-available and ready for work at the lowest wages-is an advantage from the point of view of families that want to engage part-time house help or "house boys." Some landlords take in these youth as unofficial "security guards" for buildings that are vacant or under construction, while others have them stay in the zaure, the entrance room to a house. For the youth, these practices provide shelter they would otherwise not have (Abba \& Kurfi, 2012). 
Older youth contribute to the large-scale production of the traditional embroidered caps, otherwise known in Hausa language as kube; in the Hausa/Fulani culture, wearing a kaptan and kube forms a complete formal dress code. It is typical of a Hausa/Fulani man to wear it in a professional capacity or at the office. In many instances, without the hat, it is considered an informal dress code. It is therefore not surprising that eight or nine of every ten men in Hausaland can be seen wearing the locally made caps. The demand is so large, especially in some local Hausa communities in Hausaland, that many Almajirai end up abandoning their Islamic studies and make caps as a profession.

Almajiri children have long suffered their circumstances in silence, circumstances created by adults and a failed system. Deep poverty and firmly held misinterpretations of the Quran wrongly attribute the practice to Islam, which makes it harder to reform or eliminate the practice of Almajiri. However, the twenty-first century Almajiri child could be emancipated through better alternatives designed by activists seeking to bring a sustainable solution to the suffering of children. One such solution, eTrash2Cash, uses waste management microsocial entrepreneurship support and training to give Almajiri youth economic freedom and the ability to fend for themselves, whilst pursuing Islamic knowledge.

\section{Emergence of a Local Solution to Address Two CRISES}

According to the Bauchi State Environmental Protection Agency (BASEPA) (2012), greater than 9000 metric tons of wastes is generated daily in the state. It is also estimated that about $84 \%$ of the waste contains potential reusable materials. Unfortunately, inadequate infrastructure and facilities provide the means to collect less than $10 \%$ of the total waste generated (BASEPA, 2012). Such huge amounts of uncollected waste present enormous threats to the environment, from land, air, and water pollution to deforestation, flooding, and greenhouse gas generation, especially in the face of low-income communities that live from hand to mouth. It is not uncommon to see various kinds of waste blocking the limited drainage systems within towns in the state, which causes flooding during every rainy season and also increases susceptibility to disease-causing organisms like the malarial parasite, which is most prevalent during the rainy season (BASEPA, 2012). 
In 2012, the Federal Government of Nigeria unveiled YouWiN ${ }^{6}$ through the Federal Ministry of Finance with support from the World Bank and Department for International Development (DFID) as part of its efforts to encourage youth entrepreneurship and curve youth unemployment in the country. The program supports young entrepreneurs with grants and technical assistance to launch new or support existing businesses. Based on a comprehensive feasibility analysis, undertaken by its founders with guidance from Mr. AbdulKadir Sarauta, an environmental scientist in Abubakar Tafawa Balewa University, an initiative named Haleematus-Sa'adiyya emerged as one of the pioneer beneficiaries of this program, launching in Azare (Bauchi), a northeastern state. This social enterprise was named after my youngest sister, whose name roughly translates from Arabic to English as "The Patient One." The cofounders conceived this enterprise as an emerging platform that will provide a local solution (waste management) that addresses a wide variety of social challenges (environmental impacts, Almajiri education, economic impact, etc.) in the society. Although northern Nigeria remains conservative on the issue, my personal conviction is that educating girls means educating a whole society. Along with my cofounders, I envision this social enterprise taking the path of my soon-to-be well-educated sister (and so, her name) by having an exponentially far-reaching and positive impact on the lives it touches.

The feasibility study revealed the acute need for local and sustainable waste management solutions. Surveys conducted as part of the study revealed that only $12 \%$ of community residents disposed of their waste appropriately and were aware that improper waste disposal poses risks to the environment like climate change. More than $50 \%$ could not relate the negative effects of waste burning to global warming. Less than $20 \% \mathrm{knew}$ that the majority of their waste could be potential resources.

The major town in the state, Azare, which generates almost 4000 metric tons of waste daily, has very limited government facilities in place to collect the waste from the households and industries for proper disposal. Local people and industries are left with no option but to dispose of their waste into any unauthorized landfill or open space, which in turn causes a heavy nuisance to the people.

\footnotetext{
${ }^{6}$ Youth Enterprise with Innovation in Nigeria, an initiative of the Federal Government of Nigeria to support young entrepreneurs to reduce youth unemployment (see www.youwin. org.ng).
} 
In early 2012, in the midst of growing unemployment rates and severe waste management challenges, Haleematus-Sa'adiyya Enterprises kicked off as a pioneer for-profit waste management company in Bauchi state that supports informal waste collectors (scavengers) who exchange specific types of plastic waste for money. This plastic waste is then recycled by the company into reusable polythene shopping bags for sale to small and medium enterprises (SMEs). From its inception up to the end of 2015, the company has diverted from the landfills more than 10,000 metric tons of waste, thus resulting in its reprocessing and recycling into a variety of reusable materials, such as polythene shopping bags made from plastic waste collected from the streets. The company further engaged more than 200 local waste pickers, who were thereafter transformed into some professionally trained and motivated waste managers. Thus, the company was able to change their lives.

Haleematus-Sa'adiyya Enterprises was founded by four young and passionate entrepreneurs: Muhammad Salisu Abdullahi (author), Chiroma Hassan, Usman Abubakar, and Ibrahim Sale. All four were born in Azare (Bauchi State) and have obtained bachelor's degrees in various disciplines related to the natural sciences and the environment. Having fully grown up in the local environment, they continue to work as a team to design sustainable solutions for the lingering problems of waste management to suit their local terrain and largely uninformed communities with limited awareness on waste management and climate change crisis.

Although none of them have been through the Almajiri informal system as described in this chapter, all of them have attended a formal Islamic system of education, which does not in any way present challenges like the informal one. Being indigents of the Azare community, it is very easy for them to distinguish between the two systems because of their own experience through a formal system and their encounters with the Almajiri children in day-to-day activities.

With the rapidly growing number of problems faced by the Almajiri children and the increase in population growth, which connotes an increase in quantities of waste generation in communities and the demand for holistic waste management solutions across the wider northern parts of Nigeria, the company sought the advice and help of stakeholders to officially launch another social enterprise project, called the eTrash2Cash, in 2016. This program is an independent social enterprise that would not only divert waste generated in vulnerable or low-income communities for 
sustainable environmental development but also professionally train and engage the vulnerable Almajiri youth.

Evolving as an initiative of northern Haleematus-Sa'adiyya Enterprises, eTrash2Cash enjoys partnership with another indigent non-governmental organization called the Centre for Information Technology and Development (CITAD). ${ }^{7}$ These two organizations designed a plan to take advantage of pressing community problems, seeing them as opportunities to make a positive difference or impact in the society by focusing on a subgroup of the Almajiri children. These two organizations observed that, as in any other metropolitan and commercial state in Nigeria, more than 10,000 tons of waste are being generated daily in each of Nigeria's main cities, including Kano, Kaduna, Lagos, and Ibadan. This poses a substantial threat to the environment, causing pollution; causing flooding in communities, which often leads to loss of life and property; and contributing to deforestation and greenhouse gasses that cause climate change and global warming. More worrisome, as they carefully observed, is that less than 16\% of the total waste generated in Kano State (the second largest commercial city in Nigeria with about 13 million people) is recollected and processed into reusable materials, while $84 \%$ of such waste has the potential to be reused (Hyuwa, 2010). Further, the unemployment rate is very high, with more than 100 million Nigerians earning and living on less than $\$ 1$ per day. Worst of all, this is still in a region that is inflicted with the Boko Haram insurgency, where over two million people (more than $58 \%$ youth) have been displaced from their homes, necessitating rural-urban migration on already depleted resources and worn-out social amenities.

They, therefore, unveiled eTrash2Cash to leverage technology to make positive impacts on the environment and public health and to empower the low-income and economically disadvantaged groups of young men and women to earn from their waste. This is also in addition to training a group of Almajiri children to work to expand entrepreneurship and learning opportunities for them.

${ }^{7}$ CITAD, a non-governmental organization based in the northern part of Nigeria (www. citad.org). 


\section{The ETrash2Cash Initiative}

eTrash2Cash registers low-income people in Kano, Nigeria, on its website as "waste providers" and helps them to earn cash incentives in exchange for their waste, be it plastics, papers, food, or metals. eTrash2Cash sorts this waste and makes reusable materials from them at its material and resources recovery facility (MRF) in Dakata Industrial Area in Kano State. For example, plastic floor tiles and polythene shopping bags are made from plastic wastes, tissue papers are made from paper waste, and organic fertilizer is made from food waste.

Registered households are encouraged to use their earned incentives toward supporting education for girls. Young people registered are supported in special entrepreneurship training programs to build their capacities and skills in safe waste collection, sorting, and recycling waste into reusable materials, as well as business planning, financial management, and locating funding opportunities available to them. Therefore, they earn more from their waste or become self-reliant by establishing similar or related social enterprises along the waste management value chain.

Although this initiative is owned by a for-profit venture that aims to make some profit from the waste collected and recycled to be sold to end users, its impacts are big and bold in these key areas:

- Environmental Impact: It helps to collect, evacuate, dispose, and recycle all major types of waste, which is very detrimental to air, land, and water, therefore reducing pollution from all angles, reducing flooding (preventing waste from blocking drainage systems), mitigating the harsh effects of climate change, and reducing deforestation by providing substitutes for timber from trees.

- Training Support, Social, and Job Creation Impact: It helps to train marginalized low-income youth registered as "waste providers" on waste management and entrepreneurship. Also, through its activities in waste collection, sorting, and recycling, it creates many jobs, directly and otherwise.

- Awareness and Sensitization: With our proactive online web presence and social and traditional (radio, television, newspaper) media presence using local native languages, the community is rapidly sensitized on key environmental issues and encouraged to participate. 
- Local Economy: It makes reusable products from waste exchanged for cash and also provides raw materials to support local industries and recycled end products, building up the economy.

- Educational Support: Households registered as "waste providers" are highly encouraged to use cash incentives paid to them for their waste to support education for girls in their respective homes.

So far, eTrash2Cash has 923 people registered as "waste providers" through 19 social micro-entrepreneurs in Kano, Nigeria, out of which $47 \%$ (434) are Almajiri young people, who are among the most active participants in providing all kinds of waste. The rest are low-income households and individuals. Without eTrash2Cash, the Almajiris would still be in the custody of their Mallams, studying Islamic education, because that is the primary reason they left their parents. eTrash2Cash supports them in earning a living and provides them with concrete financial support. From collecting waste and depositing it at collection hubs, they earn money based on quantities in kilogram units and the quality of the waste they provide. Through eTrash2Cash, they no longer need to engage in begging or menial jobs; the system helps them earn the minimum Nigerian wage each month.

As a payback, empowerment strategy, and of course, a social responsibility, eTrash2Cash is giving special attention and focus to this group of economically disadvantaged and most vulnerable and marginalized young people, Almajiri children, boys and girls between the ages of 9 and 14 . Through eTrash2Cash, they are empowered with relevant new knowledge and skills that can help them earn more from their waste, if they so wish, or even set up similar or related ventures on their own, all through Youth Entrepreneurship Training. To make our work easier, we work with several informal schools that have a large enrollment of Almajiri children. There has been no resistance so far from the parents, because they are not in sight, or from the Mallams, perhaps because they benefit in some way when the Almajiri children benefit, as some of them have a sharing formula on every Almajiri earning.

eTrash2Cash faced some early phase challenges in its work. They include limited literacy and numerical knowledge of vulnerable Almajiri children, which limited their comprehension and business mentoring capabilities. Another challenge is limited funding to enroll them in basic fast-track literacy and numeracy classes to enhance our impact and limited capacity as well as handle the large numbers of vulnerable children 
interested in our training programs and waste-to-wealth social microentrepreneurship.

A special thanks must be given to advocates and other communitybased supporters like the Modern Almajiri Creative School (MACS), ${ }^{8}$ which strives to shine a spotlight on the plight of the vulnerable Almajiri children, and the Mandela Washington Fellowship experience at Rutgers University in New Jersey as part of President Barack Obama's Young African Leadership Initiative program, which helped provide further research on the various sustainable methods to recover waste resources from primary sources and sustainably make bio-friendly products from them. This is especially useful during our scale-up, as large quantities and types of waste are expected to be recovered from empowered Almajiri turned micro-entrepreneurs, whose sustainability lies in the project's ability to make revenue-generating and marketable products for reuse in the communities.

\section{Local Partners that Complement the Work OF ETRASH2CASH}

One sister initiative to be highlighted is the Modern Almajiri Creative School (MACS) in Gombe State, located in the northeastern part of the country. MACS works hard to reduce vulnerability and expand youth learning and opportunity pathways in Nigeria, especially in the acquisition of vocational skills to help them earn income for the sustenance of their lives. MACS is a non-governmental organization, which seeks to empower every Almajiri youth with a modern formal education, in addition to the Islamic knowledge they are pursuing, while at the same time enrolling them into vocational centers to learn self-employment skills like carpentry, blacksmithing, and tailoring. MACS uses technology and collaborates with state governments, parents, and Mallams to streamline the whole process, from registration to vocational skills assignments, modern education enrollment, and progress tracking. So far, it has registered more than 1000 Almajiri young people, enrolled them in primary and secondary schools, and provided them access to a variety of vocational centers or workshops, where they apprentice to learn the skills and become selfemployed in those services.

\footnotetext{
${ }^{8}$ Modern Almajiri Creative School is a non-governmental organization that supports Almajiri people through formal school and vocational training.
} 
Another sister initiative worth mentioning here is the A'ishatu Bint Abubakar School located in Azare (Bauchi State), a nonprofit school that primarily targets the most vulnerable and Almajiri children in the society to acquire literacy and numeracy skills training through a formal setting under a scholarship. This formal school has supported MACS through providing scholarships to its registered Almajiri children and is continuing to advocate for formalizing the Almajiri schools to include basic literacy and numeracy knowledge.

It is imperative to note that both eTrash2Cash and MACS target the same Almajiri youth in Nigeria; while eTrash2Cash focuses specifically on supporting them through waste management microsocial entrepreneurship, MACS enrolls them into diverse entrepreneurial self-employment activities. Although there is no formal collaboration presently between the two, one of our long-term goals is to establish a working relationship, in which Almajiri youth would be registered in both programs, collecting waste to earn a living while undergoing formal school training.

\section{Conclusion}

The activities of eTrash2Cash in providing entrepreneurship training, although limited in capacity, in the waste management value chain specifically to the set of vulnerable and young people called Almajiri youth are clear strategies in expanding youth learning and opportunity pathways, but this is only the tip of the iceberg. More of such interventions in a variety of forms are needed in larger quantities and capacities, especially in the northern part of Nigeria, to accommodate the large numbers of not only the Almajiri groups, but the low-income, vulnerable, and economically disadvantaged youth in general that number in the tens of millions across the country (Daily Trust, 2011) and West Africa.

Nevertheless, for the Almajiri young people, some of the most economically disadvantaged and vulnerable groups in northern Nigeria, interventions like Youth Entrepreneurship Training programs or any vocational skills training through waste management models and other social enterprises could be replicated easily, since many cities in Africa battle with the same waste management challenges and the same Almajiri scenario. Variations of this social problem exist in so many countries in Africa, like Senegal, Ghana, Niger, Chad, and Burkina Faso. These programs would have a far-reaching impact in helping them become self-reliant and responsible young people in the society, aside from creating jobs for other people; 
positively impacting community health, education, and the local economy; and ensuring environmental sustainability in Africa and the world at large.

\section{REFERENCES}

Abba, I. A., \& Kurfi, H. M. (2012). An assessment of Kano state Almajiri pilot feeding program 2003-2007. Bayero Sociologist, A Journal of Sociological Studies, 1(2), 46-49.

Abdulkadir, I. (2010). Child street begging, A gruesome future of neglected child: The Almajiri perspective. Al-ilm Magazine, 10(7), 14-15.

Anas, L. (2017). An assessment of the Almajiranci phenomenon in Kaduna Metropolis from 1976-2006. Unpublished B.A. project, Kaduna State University, Kaduna State, Nigeria.

Babangida, I. (1993). Comparative studies between traditional Quranic schools and modern Quranic schools in Katsina State. Unpublished thesis, Ahmadu Bello University, Zaria.

Bauchi State Environmental Protection Agency (BASEPA). (2012). The role of Bauchi State Environmental Protection Agency (BASEPA) in solid waste management in Bauchi Metropolis. Maiduguri Journal of Arts and Social Sciences, 6(3), 23-26.

Daily Trust. (2011, August 9). Minister: 68m Nigerian youths out of job. Daily Trust. p. 3.

Garba, I. (1996). Qur'anic schools and their roles in U.P.E scheme in Gumel, Jigawa State. Unpublished thesis, Ahmadu Bello University, Zaria, Nigeria.

Hoechner, H. (2011). Striving for knowledge and dignity: How qur'anic students in Kano, Nigeria, learn to live with rejection and educational disadvantage. European Journal of Development Research, 23(5), 712-728.

Hoechner, H. (2015). Porridge, piety and patience: Young Qur'anic students' experience of poverty in Nigeria. Africa, 85(2), 269-288. https://doi. org/10.1017/S0001972015000029

Hyuwa, B. A. (2010, June). Solid waste management in Nigeria: An outline. Paper presented at The Maiden Annual National Conference on Environmental Challenges: Local Action Plans, Nigerian Environmental Society, Kaduna State University, Kaduna State, Nigeria.

Ibrahim, S. (2008). Menace of street begging in Kano State. National Dailies. Retrieved July 3, 2008, from http://www.nationaldalies.org

Kabir, G. (2002). Almajiri school system (4th ed.). Ibadan: Hills Publication Limited. Khalid, S. (2013, June). The Almajiranci phenomenon in northern Nigerian religious, social, economic, political, and security dimension. Paper presented at the 
National Symposium on Almajiri Education in Nigeria: The Journey So Far, Sokoto, Nigeria.

National Council for the Welfare of the Destitute. (2001). Almajir and Qur'anic education. Kaduna: Author.

Ogunmade, O. (2013, May 23). Terrorism: Mark seeks Almajiri system's ban. The Nation Online. Retrieved September 25, 2013, from http://thenationonlineng.net/terrorism-mark-seeks-almajiri-systems-ban/

Perverz, T. (2005). Situational analysis of street children in Pakistan. Retrieved July 8, 2008, from http://www.NCLPA.org

Sa'id, I. (1992). Menace of Almajiris in Kano municipal. Paper presented at Faculty of Education, Ahmadu Bello University, Zaria, Nigeria.

Salis, T. (1995). Impact of Islamic education in Kano metropolitan nursery school on Muslim children. Unpublished thesis, Ahmadu Bello University, Zaria.

Sulaiman, J. (1996). Health impact of street beggars. Journal of Medicinal Food, $10(4), 70-87$.

Sule, M. (1994). Situation of Almajiri in Nigeria. Research Journal of Education, $4(10), 23-30$.

United Nations. (2008). World population prospects: The 2008 revision. New York, NY: United Nations, Population Division of the Department of Economic and Social Affairs of the United Nations Secretariat.

Ware, R. (2014). The walking Qur'an. In Islamic education, embodied knowledge, and history in West Africa. Chapel Hill, NC: University of North Carolina University Press.

Ya'u, K. (2001). Almajiri school system in Northern Nigeria. Paper presented at conference organized by the Qur'anic Education Review committee, Katsina, Nigeria.

Open Access This chapter is licensed under the terms of the Creative Commons Attribution 4.0 International License (http://creativecommons.org/licenses/ by $/ 4.0 /)$, which permits use, sharing, adaptation, distribution and reproduction in any medium or format, as long as you give appropriate credit to the original author(s) and the source, provide a link to the Creative Commons licence and indicate if changes were made.

The images or other third party material in this chapter are included in the chapter's Creative Commons licence, unless indicated otherwise in a credit line to the material. If material is not included in the chapter's Creative Commons licence and your intended use is not permitted by statutory regulation or exceeds the permitted use, you will need to obtain permission directly from the copyright holder.

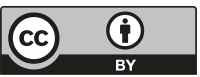

